Article

\title{
Assessment of 16 Peanut (Arachis hypogaea L.) CSSLs Derived from an Interspecific Cross for Yield and Yield Component Traits: QTL Validation
}

\author{
Hodo-Abalo Tossim ${ }^{1,2}$, Joel Romaric Nguepjop ${ }^{1,3}$, Cyril Diatta ${ }^{4}$, Aissatou Sambou ${ }^{1}$, \\ Maguette Seye ${ }^{1}$, Djibril Sane ${ }^{2}$, Jean-François Rami ${ }^{5,6}$ and Daniel Fonceka ${ }^{1,6,7, *}$ \\ 1 Centre d'Etude Régional pour l'Amélioration de l'Adaptation à la Sécheresse (CERAAS), Institut Sénégalais \\ de Recherches Agricoles (ISRA), Route de Khombole, Thiès BP 3320, Senegal; aristossim@yahoo.fr \\ 2 Département de Biologie Végétale, Faculté des Sciences et Techniques, Université Cheih Anta Diop de Dakar, \\ Dakar BP 5005, Senegal \\ 3 Institut Universitaire de Technologies Bois-Mbalmayo, Université de Yaoundé 1, Mbalmayo BP 306, \\ Yaoundé, Cameroun \\ 4 Centre National de Recherche Agronomique (CNRA), Institut Sénégalais de Recherches Agricoles (ISRA), \\ Bambey BP 53, Senegal \\ 5 CIRAD, UMR AGAP, F-34398 Montpellier, France \\ 6 AGAP, Univ Montpellier, CIRAD, INRAE, Montpellier SupAgro, 34090 Montpellier, France \\ 7 CIRAD, UMR AGAP, Thies BP 3320, Senegal \\ * Correspondence: daniel.fonceka@cirad.fr
}

Received: 8 April 2020; Accepted: 15 April 2020; Published: 18 April 2020

\begin{abstract}
Cultivated peanut is an allotetraploid $(2 n=4 \times=40)$ with narrow genetic diversity. In previous studies, we developed an advanced backcross quantitative trait loci (AB-QTL) population

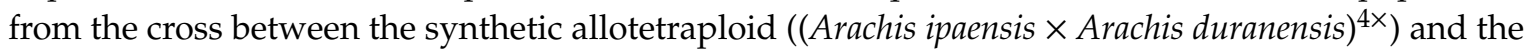
cultivated variety Fleur11, and mapped several quantitative trait loci (QTLs) involved in yield and yield components. We also developed a chromosome segment substitution line (CSSL) population as a way to mendelize the QTLs and analyzing their effects. In this study, 16 CSSLs were used for assessing the contribution of wild alleles in yield performance and stability across environments, as well as validating QTLs for pod and seed size. The CSSLs and the recurrent parent Fleur11, used as a check, were assessed using an alpha lattice design in three locations during two consecutive rainy seasons in Senegal, totaling six environments. Our results showed that the chromosome segments from the wild species, in general, have no yield disadvantage and contributed positive variation to yield-related traits. Most of the QTLs detected for pod and seed size in the AB-QTL on linkage groups A07, A08, A09, and B06 were also found in the CSSLs, showing that the CSSLs used in this study are accurate material for QTL validation. Several new QTLs have also been identified. Two CSSLs (12CS_031 and 12CS_069) showed consistently higher pod and seed size than Fleur11 in all environments, suggesting that the QTLs were consistent and stable. Our study opens the way for pyramiding these QTLs for peanut improvement.
\end{abstract}

Keywords: peanut; wild species; seed size; yield; QTL validation; AB-QTL; CSSL

\section{Introduction}

Peanut (Arachis hypogaea L.), also called groundnut, is a major oil crop, along with soybean, rapeseed, sunflower, and cotton. It is mainly grown by resource-poor farmers in Africa and Asia to produce edible oil for human consumption. It also provides by-products for animal feeding. Peanuts are a complete food and ingredient, because they provide the highest protein content of all 
commonly consumed snack nuts, constitute a rich source of heart-healthy monounsaturated oil, and also provide a variety of micronutrients and bioactive compounds [1]. Peanut yield varies greatly between continents, production regions, and within regions in the same country. The highest yields $\left(3.3 \mathrm{t} \cdot \mathrm{ha}^{-1}\right.$ and $2.18 \mathrm{t} \cdot \mathrm{ha}^{-1}$ ) are found in America and in Asia, respectively, while lowest yield ( $\left.0.9 \mathrm{t} \cdot \mathrm{ha}^{-1}\right)$ is recorded in Africa [2].

The peanut (Arachis hypogaea L.) is an allotetraploid $(2 n=4 \times=40)$, and along with its wild relatives is native to South America [3-7]. Cultivated peanut belongs to the section Arachis and arose from a single hybridization event between the wild diploid species Arachis duranensis (A genome) and Arachis ipaensis (B genome) [6-10]. This single hybridization event resulted in a severe bottleneck, which, superimposed with the effects of the domestication, has greatly narrowed the genetic diversity of the cultivated species. In contrast, wild species that adapt perfectly to marginal environments harbor a great level of DNA diversity and represent an untapped reservoir of genes that can be used for peanut improvement [9,11-18].

In the last three decades, many authors reported the use of wild crop relatives to improve cultivated species, including tomato [19-22], rice [23-27], barley, wheat [28-30], and pepper [31-33]. However, the use of wild species in peanut breeding programs has long been impeded by the difference in ploidy level (cultivated peanut is allotetraploid, while the wild relatives are mostly diploids) and the lack of DNA markers for monitoring the introgression of the wild alleles in the cultivated genetic background [34,35]. The potential of wild species for peanut improvement has been recently unlocked with the development of wild synthetic tetraploids that allow the movement genes from the wild to the cultivated species and with a tremendous increase of molecular markers [36-39]. This progress also led to the introgression of several traits of agronomical interest in peanut elite cultivars (for review, see [40,41]). Furthermore, it allowed the development of quantitative trait loci (QTL) mapping populations and the identification of genomic regions from the wild species that are involved in disease resistance [42-44], drought tolerance [45], and the variation of yield component traits [46,47]. When using wild species in crop improvement, advanced backcross quantitative loci (AB-QTL) and chromosomal segment substitution line (CSSL) populations are very informative to detect and map valuable QTLs, and to simultaneously transfer them from wild to cultivated species $[48,49]$. Such populations have been developed in peanut, using $(\text { A ipaensis }(\mathrm{BB} \text { genome }) \times A \text {. duranensis (AA genome) })^{4 \times}$ as an interspecific hybrid donor parent and Fleur11 as the female parent $[47,50,51]$. In the study involving the AB-QTL population, several QTLs involved in yield components, such as pod and seed size, were mapped [47]. These QTLs explained up to $58 \%$ of the phenotypic variation for seed and pod size traits. In the CSSL population [51], introgression lines were identified that carry the QTL regions. In this study, we used 16 CSSLs, selected based on the correspondence between the location of their introgressions and the position of the QTL in the earlier AB-QTL study [47], as well as on phenotypic information for validating the QTLs and for precisely determining their effects on selected traits. These lines were evaluated in three locations over two years, totaling six environments, to investigate the contribution of the wild QTL alleles for improving yield and yield components, including hundred seed weight (HSW) and pod and seed length (PL and SL, respectively) and width (PWI and SWI, respectively), as well as their stability across environments. Our results confirm the strong effectiveness of combining AB-QTL and CSSL approaches for QTL validation, discovering new QTL, and highlighting the favorable role of wild species alleles for peanut improvement.

\section{Material and Methods}

\subsection{Plant Material}

The plant material used in this study included 16 chromosome segment substitution lines (CSSLs) derived from the cross between the synthetic allotetraploid (A. ipaensis K30076 $\times$ A. duranensis V14167) ${ }^{4 \times}$ and a cultivated variety, Fleur11 [50,51] (Table 1, Figure 1). Fourteen CSSLs were selected based on the presence of an introgression corresponding to QTL position in the previous AB-QTL study [47]. 
Two additional CSSLs (12CS_048 and 12CS_006) were added to the study, based on the results of an unpublished drought phenotyping experiment. Fleur11 was used as the reference cultivated genotype to assess the effect of wild introgressions.

Table 1. Selected chromosome segment substitution lines (CSSLs) with corresponding quantitative trait locus (QTL) regions in the advanced backcross quantitative loci (AB-QTL) study.

\begin{tabular}{ccc}
\hline Lines & Linkage Group & QTLs from AB-QTL Study \\
\hline 12CS_075 & A01 & $q P N ; q P W ; q S H W$ \\
12CS_115 & A01 & $q P N ; q P W ; q S H W$ \\
12CS_120 & A01 & $q P N ; q P W ; q S H W$ \\
12CS_052 & A02 & $q H W$ \\
12CS_098 & A04 & $q P H$ \\
12CS_091 & A07 & $q H S W ; q P L ; q P W I ; q S L ; q S W I$ \\
12CS_034 & A07 & $q H S W ; q P L ; q P W I ; q S L ; q S W I$ \\
12CS_039 & A08 & $q P L ; q P W I ; q S L$ \\
12CS_028 & A09 & $q P L ; q S L$ \\
12CS_031 & A09 & $q P L ; q S L$ \\
12CS_037 & B05 & $q H P W ; q P W I ; q S W I ; q S W$ \\
12CS_050 & B06 & $q P W I, q S W I ; q T B ; q H W ; q P M A T$ \\
12CS_069 & B06 & $q P W I, q S W I ; q T B ; q H W ; q P M A T$ \\
12CS_068 & B11 & $q P M A T$ \\
12CS_048 & B07 & - \\
12CS_006 & B08 & - \\
Fleur11 & - & - \\
\hline
\end{tabular}

q: QTL, PN: pod number per plant, PW: pod weight per plant, SHW: shell weight, HW: haulm weight per plant, PH: height of the main stem, HSW: 100 seed weight, PL: pod length, SL: seed length, SWI: seed width, HPW: 100-pod weight, TB: total biomass, PMAT: percentage of pod maturity.

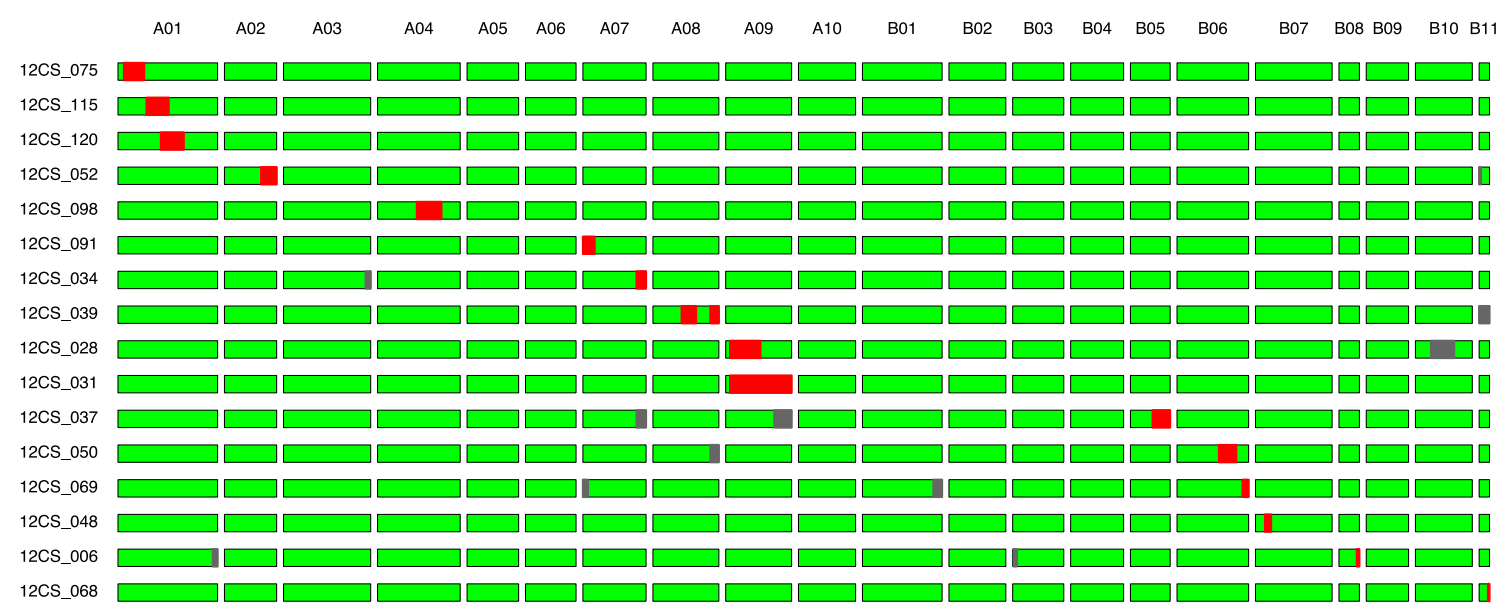

Figure 1. Graphical genotypes of the CSSLs used in this study. The CSSLs are represented in rows and chromosomes are in columns. Green: genetic background of Fleur11. Red: target introgression from the wild species. Grey: non-target wild introgressions.

\subsection{Experimental Design and Trial Management}

The experiments were conducted during the rainy seasons of 2014 and 2015 in three ISRA (Institut Sénégalais de Recherches Agricoles) research stations in Senegal: Darou $\left(13^{\circ} 43^{\prime} \mathrm{N} ; 15^{\circ} 46^{\prime} \mathrm{W}\right)$, Nioro $\left(13^{\circ} 44^{\prime} \mathrm{N} ; 15^{\circ} 46^{\prime} \mathrm{W}\right)$ and Sinthiou Malème $\left(13^{\circ} 46^{\prime} \mathrm{N} ; 13^{\circ} 40^{\prime} \mathrm{W}\right)$. An alpha-lattice experimental design was used at each location, with three replications, two blocks per replication, and nine plots in each block. Fleur11 was repeated twice in each replication. The plot size was $18 \mathrm{~m}^{2}$. Each plot had six rows at $6 \mathrm{~m}$ long each, with spacing between rows and between plants of $50 \mathrm{~cm}$ and $15 \mathrm{~cm}$, respectively. Seeds were previously treated with GRANOX (10\% Captafol, $10 \%$ benomyl, and $20 \%$ carbofuran) to avoid seedling collar rot. Sowing and weeds control were done manually. A total of $150 \mathrm{~kg} \mathrm{ha}^{-1}$ of 
$\mathrm{N} / \mathrm{P} / \mathrm{K}$ (6-20-10) fertilizer was applied in two steps, half at 15 days after planting and the remaining at 50 days after planting.

\subsection{Rainfall Amount in the Six Environnements}

In 2014 and 2015, the total amounts of precipitation recorded during the experiments were $350 \mathrm{~mm}$ and $576 \mathrm{~mm}$ in Darou, $475 \mathrm{~mm}$ and $943 \mathrm{~mm}$ in Nioro, and $638 \mathrm{~mm}$ and $522 \mathrm{~mm}$ in Sinthiou respectively.

\subsection{Harvest and Post-Harvest Management}

The plots were dug at 95 days after planting (DAP). The harvested area of each plot was $8 \mathrm{~m}^{2}$. All harvested plants were exposed to ambient temperature $\left(30-35^{\circ} \mathrm{C}\right)$ for one month to allow complete drying of pods and haulms.

\subsection{Traits Evaluated}

A total of nine traits were evaluated across the six environments: pod and haulm yield (Yield, Hlm), pod maturity (Mat), 100 pod and seed weight (HPW and HSW, respectively), pod and seed length (PL and SL), and pod and seed width (PWI and SWI).

\subsubsection{Pod and Haulm Yield}

To estimate the pod yield (Yield) and haulm yield (Hlm), the total dry biomass harvested on $8 \mathrm{~m}^{2}$ was first weighed, then pods were removed from haulm and weighed. Haulm dry weight was obtained by subtracting the pod dry weight from the total dry biomass. Pod and haulm yields were expressed in $\mathrm{t} \cdot \mathrm{ha}^{-1}$.

\subsubsection{Yield Components}

One hundred pod weight (HPW) and 100 seed weight (HSW) were measured by the weight of a random sample of 100 pods, and the weight of all mature seeds of the same sample divided by the total number of mature seeds multiplied by 100, respectively. The percentage of pod maturity (Mat) was assessed on 100 pods, using the dark internal pericarp color scoring method.

\subsubsection{Pod and Seed Sizes}

The length and width of pods (PL and PWI, respectively) and seeds (SL and SWI, respectively) were measured from a random sample each of 30 pods and 30 seeds, respectively, using a caliper with digital display.

\subsection{Statistical Analysis}

In a first step, single-site analyses were conducted for each environment (location $\times$ year). In each environment, adjusted means and heritabilities were computed using a mixed model, as implemented in the R package statgenSTA [52]. Genotypes were treated as fixed for the calculation of the best linear unbiased estimator (BLUEs), and as random for the estimation of heritabilities. The model fitted to experimental field data was

$$
Y_{i j k}=\mu+G_{i}+r_{j}+b_{j k}+\varepsilon
$$

where $Y_{i j k}$ is the observed value for a given trait, $\mu$ is the mean of the population, $G_{i}$ is either the fixed genotype effect or the random genotype effect with $G_{i} \sim N\left(0, \sigma_{g}^{2}\right), r_{j}$ is the fixed replication effect, $b_{j k}$ is the random block within replication effect, and $\varepsilon$ is the residual error. Estimates of broad-sense heritability $\left(h^{2}\right)$ were calculated for each environment as

$$
h^{2}=\frac{\sigma_{G}^{2}}{\sigma_{G}^{2}+\frac{\sigma_{E}^{2}}{n r e p}}
$$


where $\sigma_{G}^{2}$ is the genotypic variance, $\sigma_{E}^{2}$ the residual variance, and nrep the number of replications.

When the analysis revealed a significant genotype effect, a DUNNETT's multiple comparison test at $5 \%$ threshold was performed in order to compare each genotype to Fleur11, using the R package multcomp [53]. For each CSSL that showed a significant difference with Fleur11, a relative difference $(R D)$ was computed as

$$
R D_{C S S L}=\frac{B L U E_{C S S L}-B L U E_{\text {Fleur11 }}}{B L U E_{\text {Fleur } 11}} \times 100
$$

In a second step, multi-environment trial (MET) analyses were conducted using the BLUE values and standard errors of each environment obtained from the first step. An additive main effects and multiplicative interaction (AMMI) model was first fitted to the pod Yield trait, with the objective of clustering the six environments into mega-environments, based on the winning genotype approach. A genotype main effects and genotype $\times$ environment interaction effects (GGE) model [54] was fitted to each trait, using the mega-environment previously identified as an environmental factor. For each genotype, a stability coefficient (SC) was computed as the sum of the squares of the difference between its mean and the mean of the best genotype in each environment, divided by twice the number of environments. Genotypes with the smallest coefficient are more stable, and closer to the best genotypes in each environment. All MET analyses were performed using the Breeding View software that is available as part of the Breeding Management System [55].

\section{Results}

\subsection{Single-Site Analysis and Comparison between CSSLs and Fleur11}

Significant genotype effects were found for each trait in the six environments (Table 2). Broad sense heritability was calculated for each environments. High values of broad sense heritability were observed for all traits at each location, except for pod maturity in Darou and Nioro in 2015 (Table 2).

Table 2. Variance components for fixed effects of single-site mixed-model analyses.

\begin{tabular}{|c|c|c|c|c|c|c|c|c|c|c|c|c|c|}
\hline \multirow[b]{2}{*}{ Trait } & \multirow[b]{2}{*}{ Term } & \multicolumn{3}{|c|}{ D14 } & \multirow[b]{2}{*}{$h^{2}$} & \multicolumn{3}{|c|}{ D15 } & \multicolumn{5}{|c|}{ N14 } \\
\hline & & mean & F & $\operatorname{Pr}$ & & Mean & F & Pr & $h^{2}$ & Mean & $\mathbf{F}$ & Pr & $h^{2}$ \\
\hline \multirow{2}{*}{ Hlm } & genotype & & 29.16 & $<0.001^{* * *}$ & \multirow{2}{*}{0.81} & \multirow{2}{*}{2.43} & 7.63 & $<0.001^{* * *}$ & \multirow{2}{*}{0.73} & \multirow[b]{2}{*}{2.99} & 21.3 & $0.003^{* *}$ & \multirow{2}{*}{0.55} \\
\hline & rep & 1.92 & 0.47 & 0.247 & & & 3.79 & $<0.001^{* * *}$ & & & 7.23 & $0.008 * *$ & \\
\hline \multirow{2}{*}{ HPW } & genotype & & 12.58 & $<0.001^{* * *}$ & \multirow{2}{*}{0.88} & \multirow{2}{*}{129.16} & 1.18 & $<0.001^{* * *}$ & \multirow{2}{*}{0.91} & \multirow{2}{*}{134.10} & 38.66 & $<0.001^{* * *}$ & \multirow{2}{*}{0.74} \\
\hline & rep & 111.94 & 0.59 & 0.083 & & & 0.26 & 0.386 & & & 2.41 & 0.662 & \\
\hline \multirow{2}{*}{ HSW } & genotype & 5895 & 3.72 & $<0.001^{* * *}$ & \multirow{2}{*}{0.89} & \multirow{2}{*}{56.04} & 2.26 & $<0.001^{* * *}$ & \multirow{2}{*}{0.93} & \multirow{2}{*}{58.31} & 3.86 & $<0.001^{* * *}$ & \multirow{2}{*}{0.87} \\
\hline & rep & 58.95 & 0.05 & $0.001 * *$ & & & 4.87 & 0.554 & & & 0.41 & 0.104 & \\
\hline \multirow{2}{*}{ Mat } & genotype & & 11.41 & $<0.001^{* * *}$ & \multirow[b]{2}{*}{0.60} & \multirow{2}{*}{89.61} & 14.56 & 0.275 & \multirow{2}{*}{0.09} & \multirow[b]{2}{*}{88.65} & 15.93 & $0.004^{* *}$ & \multirow{2}{*}{0.53} \\
\hline & rep & 62.20 & 3.09 & 0.974 & & & 1.25 & 0.77 & & & 0.79 & 0.277 & \\
\hline \multirow{2}{*}{ PL } & genotype & & 7.68 & $<0.001^{* * *}$ & \multirow{2}{*}{0.92} & & 1.16 & $<0.001^{* * *}$ & & & 14.7 & $<0.001^{* * *}$ & \\
\hline & rep & 28.17 & 0.51 & 0.885 & & 28.77 & 0.08 & 0.090 & 0.97 & 28.17 & 0.69 & 0.13 & 0.89 \\
\hline & genotype & & 3.99 & $<0.001^{* * *}$ & & & 5.06 & $<0.001^{* * *}$ & & & 4.1 & $<0.001^{* * *}$ & \\
\hline PWI & rep & 11.80 & 0.26 & 0.626 & 0.97 & 11.33 & 17.93 & 0.064 & 0.90 & 11.76 & 0.47 & $0.046^{*}$ & 0.91 \\
\hline SI & genotype & 14.45 & 44.78 & $<0.001^{* * *}$ & 084 & 1457 & 17.93 & $<0.001^{* * *}$ & 096 & 1434 & 11.96 & $<0.001^{* * *}$ & 093 \\
\hline SL & rep & 14.45 & 7.03 & $0.023 *$ & 0.84 & & 1.11 & 0.54 & 0.96 & 14.34 & 5.36 & 0.287 & 0.93 \\
\hline SWI & genotype & 870 & 22.24 & $<0.001^{* * *}$ & & & 1.98 & $<0.001^{* * *}$ & & & 34.39 & $<0.001^{* * *}$ & 0.94 \\
\hline SWvi & rep & 8.70 & 2.7 & $<0.001^{* * *}$ & 0.95 & 8.35 & 2.55 & 0.687 & 0.94 & 8.69 & 4.07 & 0.452 & 0.94 \\
\hline Yield & genotype & 1.77 & 4.85 & $<0.001^{* * *}$ & 0.81 & 1.90 & 5.48 & $<0.001^{* * *}$ & 0.88 & 2.65 & 8.05 & $<0.001^{* * *}$ & 0.73 \\
\hline пега & rep & 1.77 & 2.49 & 0.107 & 0.81 & 1.90 & 1.38 & $<0.001^{* * *}$ & 0.88 & 2.65 & 2.49 & 0.954 & 0.73 \\
\hline
\end{tabular}


Table 2. Cont.

\begin{tabular}{|c|c|c|c|c|c|c|c|c|c|c|c|c|c|}
\hline \multirow[b]{2}{*}{ Trait } & \multirow[b]{2}{*}{ Term } & \multicolumn{3}{|c|}{ N15 } & \multirow[b]{2}{*}{$h^{2}$} & \multicolumn{3}{|c|}{ S14 } & \multicolumn{5}{|c|}{ S15 } \\
\hline & & mean & F & Pr & & mean & F & $\operatorname{Pr}$ & $h^{2}$ & mean & F & Pr & $h^{2}$ \\
\hline Hlm & $\begin{array}{l}\text { genotype } \\
\text { rep }\end{array}$ & 3.48 & $\begin{array}{c}8.26 \\
15.51\end{array}$ & $\begin{array}{c}<0.001 * * * \\
0.673\end{array}$ & 0.89 & 5.30 & $\begin{array}{l}3.79 \\
10.5\end{array}$ & $\begin{array}{l}<0.001^{* * *} \\
<0.001 * * *\end{array}$ & 0.79 & 4.60 & $\begin{array}{c}11.39 \\
0.95\end{array}$ & $\begin{array}{c}0.002 * * \\
<0.001 * * *\end{array}$ & 0.56 \\
\hline HPW & $\begin{array}{c}\text { genotype } \\
\text { rep }\end{array}$ & 121.42 & $\begin{array}{l}9.95 \\
2.74\end{array}$ & $\begin{array}{c}<0.001^{* * *} \\
0.545\end{array}$ & 0.79 & 105.20 & $\begin{array}{c}24.28 \\
0.62\end{array}$ & $\begin{array}{c}<0.001^{* * *} \\
0.627\end{array}$ & 0.75 & 111.86 & $\begin{array}{c}15.46 \\
0.37\end{array}$ & $\begin{array}{c}<0.001^{* * *} \\
0.563\end{array}$ & 0.84 \\
\hline HSW & $\begin{array}{l}\text { genotype } \\
\text { rep }\end{array}$ & 52.69 & $\begin{array}{l}7.94 \\
2.26\end{array}$ & $\begin{array}{c}<0.001^{* * *} \\
0.603\end{array}$ & 0.87 & 59.06 & $\begin{array}{l}2.17 \\
1.28\end{array}$ & $\begin{array}{c}<0.001^{* * *} \\
0.089\end{array}$ & 0.96 & 57.56 & $\begin{array}{l}9.36 \\
2.04\end{array}$ & $\begin{array}{c}<0.001^{* * *} \\
0.135\end{array}$ & 0.96 \\
\hline Mat & $\begin{array}{l}\text { genotype } \\
\text { rep }\end{array}$ & 91.61 & $\begin{array}{l}3.94 \\
0.46\end{array}$ & $\begin{array}{l}0.296 \\
0.925\end{array}$ & 0.15 & 77.71 & $\begin{array}{l}9.4 \\
0.4\end{array}$ & $\begin{array}{c}<0.001^{* * *} \\
0.376\end{array}$ & 0.70 & 77.59 & $\begin{array}{l}5.18 \\
0.61\end{array}$ & $\begin{array}{c}0.011 * \\
0.078\end{array}$ & 0.46 \\
\hline PL & $\begin{array}{l}\text { genotype } \\
\text { rep }\end{array}$ & 27.21 & $\begin{array}{l}7.53 \\
1.52\end{array}$ & $\begin{array}{c}<0.001^{* * *} \\
0.499\end{array}$ & 0.93 & 27.56 & $\begin{array}{l}8.19 \\
3.22\end{array}$ & $\begin{array}{c}<0.001^{* * *} \\
0.658\end{array}$ & 0.92 & 28.66 & $\begin{array}{l}6.57 \\
2.11\end{array}$ & $\begin{array}{c}<0.001^{* * *} \\
0.017^{*}\end{array}$ & 0.97 \\
\hline PWI & $\begin{array}{l}\text { genotype } \\
\text { rep }\end{array}$ & 10.96 & $\begin{array}{c}27.38 \\
2.42\end{array}$ & $\begin{array}{c}<0.001^{* * *} \\
0.218\end{array}$ & 0.86 & 11.43 & $\begin{array}{l}3.42 \\
0.98\end{array}$ & $\begin{array}{l}<0.001^{* * *} \\
<0.001^{* * *}\end{array}$ & 0.98 & 11.31 & $\begin{array}{c}11.86 \\
0.42\end{array}$ & $\begin{array}{c}<0.001^{* * *} \\
0.392\end{array}$ & 0.97 \\
\hline SL & $\begin{array}{c}\text { genotype } \\
\text { rep }\end{array}$ & 13.94 & $\begin{array}{l}5.16 \\
0.21\end{array}$ & $\begin{array}{c}<0.001 * * * \\
0.040^{*}\end{array}$ & 0.87 & 14.38 & $\begin{array}{c}2.32 \\
12.41\end{array}$ & $\begin{array}{c}<0.001^{* * *} \\
0.329\end{array}$ & 0.95 & 14.46 & $\begin{array}{l}6.08 \\
0.33\end{array}$ & $\begin{array}{c}<0.001^{* * *} \\
0.25\end{array}$ & 0.92 \\
\hline SWI & $\begin{array}{c}\text { genotype } \\
\text { rep }\end{array}$ & 8.04 & $\begin{array}{c}38.13 \\
0.94\end{array}$ & $\begin{array}{c}<0.001^{* * *} \\
0.121\end{array}$ & 0.85 & 8.31 & $\begin{array}{c}12.76 \\
1.39\end{array}$ & $\begin{array}{c}<0.001^{* * *} \\
0.005^{* *}\end{array}$ & 0.91 & 8.43 & $\begin{array}{c}17.04 \\
5.49\end{array}$ & $\begin{array}{c}<0.001^{* * *} \\
0.004^{* *}\end{array}$ & 0.94 \\
\hline Yield & $\begin{array}{c}\text { genotype } \\
\text { rep }\end{array}$ & 2.77 & $\begin{array}{l}9.24 \\
6.72\end{array}$ & $\begin{array}{c}<0.001^{* * *} \\
0.633\end{array}$ & 0.74 & 2.12 & $\begin{array}{l}2.58 \\
0.03\end{array}$ & $\begin{array}{c}<0.0011^{* * *} \\
0.773\end{array}$ & 0.71 & 2.55 & $\begin{array}{c}12.03 \\
0.12\end{array}$ & $\begin{array}{c}<0.001^{* * *} \\
0.814\end{array}$ & 0.79 \\
\hline
\end{tabular}

Hlm: Haulm yield (t.ha ${ }^{-1}$ ); HPW: hundred pod weight (g); HSW: hundred seed weight (g); Mat: percentage of pod maturity; PL: pod length (mm); SL: seed length $(\mathrm{mm})$; PWI: pod width $(\mathrm{mm})$; SWI: seed width $(\mathrm{mm})$, Yield: pod yield $\left(\mathrm{t} \cdot \mathrm{ha}^{-1}\right)$. Mean: overall mean value of the trait in each environment; F: $F$-statistic value; Pr: $p$-value associated to $F$-test; $h^{2}$ : broad sense heritability. ${ }^{*}, * * * * *$ Significant at $p<0.05, p<0.005$ and $p<0.001$, respectively.

\subsubsection{Hundred Pod and Seed Weights (HPW and HSW)}

For the HPW trait, the DUNNETT's comparison showed that 12CS_069 outperformed Fleur11 in D15 and N14 environments and 12CS_031 in D14 and N15 environments (Figure 2, Figure S1, Table S1). The relative difference compared to Fleur11 ranged from $+14.1 \%$ to $+27.5 \%$, corresponding to $18.2 \mathrm{~g}$ and 32.9 g, respectively. Remarkably, 12CS_091 has consistently lower HPW in all environments. The relative difference compared to Fleur11 ranged from $-26.0 \%$ to $-41.4 \%$, corresponding to $-30.3 \mathrm{~g}$ and $-53.4 \mathrm{~g}$, respectively.

For the HSW trait, the same two CSSLs (i.e., 12CS_031 and 12CS_069), significantly outperformed Fleur11 in all environments (Figure 2, Figure S2, Table S1). The relative difference compared to Fleur 11 ranged from $+9.3 \%$ to $+20.6 \%$, corresponding to $5.5 \mathrm{~g}$ and $11.05 \mathrm{~g}$, respectively. In addition, 12CS_034 showed significant increase over Fleur11 only in the Sinthiou location (S14 and S15), and two lines (12CS_050 and 12CS_115) outperformed Fleur11 in S15. However two lines (12CS_006 and 12CS_037) underperformed Fleur11 in S14. The 12CS_091 CSSL has lower HSW in all environments. The relative difference compared to Fleur 11 ranged from $-13.1 \%$ to $-36.0 \%$, corresponding to $-7.7 \mathrm{~g}$ and $-21.3 \mathrm{~g}$, respectively. 

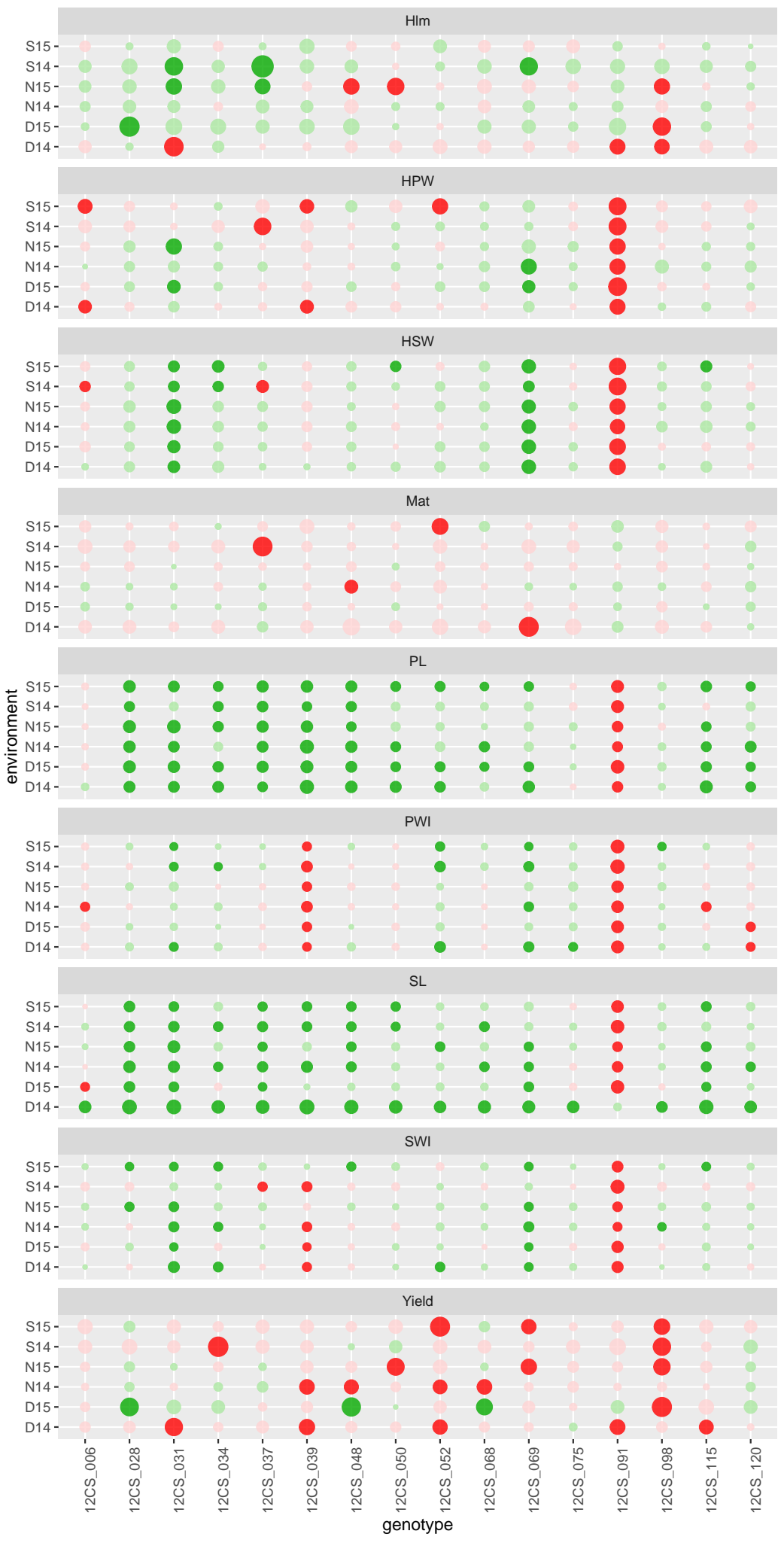

Relative difference (\%): $20 \bigcirc 40 \bigcirc 60$

Sign and significativity of relative diff.: $\begin{array}{ll}\text { - Negative-significative } & \text { Positive-non-significative } \\ \text { Negative-non-significative } & \bullet \text { Positive-significative }\end{array}$

Figure 2. Relative difference between the CSSLs and Fleur11 for all traits across the six environments. Hlm (haulm yield); HPW (100 pod weight); HSW (100 seed weight); Mat (percentage of pod maturity); PL (pod length); SL (seed length); PWI (pod width); SWI (seed width); Yield (pod yield). 


\subsubsection{Pod and Seed Length (PL and SL)}

For PL, seven CSSLs (12CS_028, 12CS_031, 12CS_034, 12CS_037, 12CS_039, 12CS_048, and 12CS_115) significantly outperformed Fleur11 in at least five out of six environments $(p<0.05$ to $p<0.001$ ), with a relative difference ranging from $+6.0 \%$ in to $+17.6 \%$. Overall, 12 CS_039 was the best genotype in most environments (Figure 2, Figure S3, Table S2). Additionally, five CSSLs (12CS_050, 12CS_052, 12CS_068, 12CS_069, and 12CS_120) also have significantly longer pods than Fleur11 in three or four environments. Similar to what was observed for HWP and HSW traits, 12CS_091 had the lowest PL value with a relative difference compared to Fleur11, ranging from $-7 \%$ to $-15.3 \%$.

Most of the CSSLs that outperformed Fleur11 for PL also have significantly longer seed length (SL) than Fleur11. For example, the lines 12CS_028, 12CS_031, and 12CS_037 had significant higher SL than Fleur11 in all environments, with a relative difference ranging from $+3.9 \%$ to $+20.5 \%$ (Figure 2, Figure S4, Table S2). Again, 12CS_091 had the lowest SL values in all environments.

\subsubsection{Pod and Seed Width (PWI and SWI)}

For pod width (PWI), 12CS_031, 12CS_052, and 12CS_069 has significantly larger pods than Fleur11 in at least four environments $(p<0.05$ to $p<0.001)$, with relative differences compared to Fleur11 reaching $+8.5 \%$ in S14 for 12CS_052. Additionally, 12CS_034, 12CS_075, and 12CS_098 outperformed Fleur11 in S14, D14, and S15, respectively (Figure 2, Figure S5, Table S3).

For the seed width (SWI) trait, two CSSLs (12CS_031 and 12CS_069) outperformed Fleur11 in five environments. The relative difference compared to Fleur 11 ranged from $+3.5 \%$ to $+10.0 \%$. In addition, six CSSLs (12CS_028, 12CS_048, 12CS_052, 12CS_098, and 12CS_115) were significantly superior to Fleur11 at least in one environment. As for the other traits, 12CS_091 had the lowest SWI value in all environments (Figure 2, Figure S6, Table S3).

\subsubsection{Pod and Haulm Yield (Yield, Hlm) and Pod Maturity (Mat)}

A pod yield comparison between CSSLs and Fleur11 showed that none of the CSSLs had significantly higher or lower yields than Fleur11 across all environments. Three lines (12CS_028, 12CS_048, and 12CS_068) exhibited significantly higher yields than Fleur11 in Darou 2015, and 11 lines had significantly lower yields in at least one environment (Figure 2, Figure S7, Table S4). Surprisingly, 12CS_091 had a significantly lower yield than Fleur11 in only one environment, albeit with smaller pods in all environments. Conversely, some lines (12CS_034, 12CS_052, 12CS_069, and 12CS_098) had a significantly lower yield than Fleur11 in two to four environments, albeit with larger pods. Four lines (12CS_028, 12CS_031, 12CS_037, and 12CS_069) have a significantly higher haulm yield (Hlm) than Fleur11, and none of the lines had a higher percentage of pod maturity than Fleur11 (Figure 2, Figures S8 and S9, Table S4).

\subsection{Mega-Environments, Performance, and Stability of the Genotypes}

AMMI analysis was first performed on pod yield, and mega-environments were determined based on the winning genotype in each environment. Five mega-environments were identified. The first mega-environment clustered S15 and N15 together, with 12CS_028 as the winning genotype. D14, D15, N14, and S14 constituted one mega-environment each, with 12CS_120, 12CS_068, 12CS_037, and 12CS_050 as winning genotypes, respectively (Figure 3). AMMI analyses were then performed for the other traits, using the mega-environments identified for Yield. Results for the analysis of variance table from AMMI showed a significant additive main effect (genotypes and environments) and multiplicative interaction effects (GxE captured in IPCA1 and IPCA2) for all traits (Table S5). Genotype effects explained a larger part of the total variation for seed and pod size-related traits, ranging from $40 \%$ for HPW to $72 \%$ for HSW. Conversely, environments explained most of the variation for yield traits, ranging from $39.2 \%$ for pod yield to $76.8 \%$ for haulm yield. 


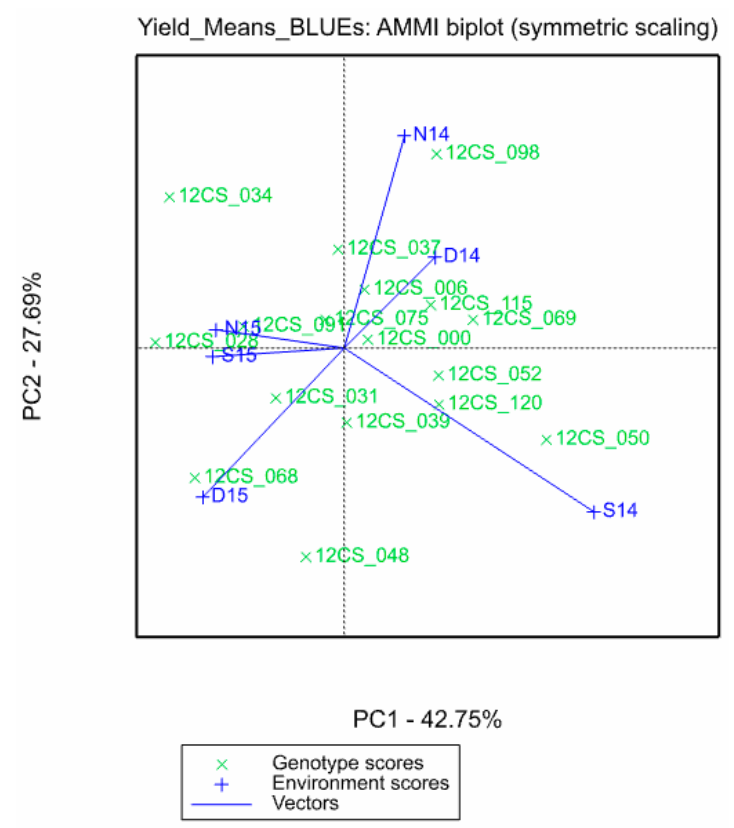

Figure 3. Additive main effects and multiplicative interaction (AMMI) biplot for pod yield using 16 CSSLs and Fleur11 tested in six environments. Genotypes are represented in green and environments in blue. Fleur11 is referred to as 12CS_000.

For all traits, a GGE biplot analysis was used to assess the effects of the genotype's main effects and GxE interaction, using the mega-environments defined in AMMI analysis. Here we show the results for pod yield, Hlm, and HSW. For pod yield, the first two principal components (PC1 and PC2) explained $69.4 \%$ of the total Genotype plus Genotype by Environment interaction (G + GE). The polygon view of GGE biplot analysis showed five genotypes section and three environmental sections (mega-environments). Environments were clustered into a mega-environment with all 2015 locations, as well as three mega-environments for each location of 2014 (Figure 4a). This environmental clustering differed slightly from what was obtained with AMMI. However, the winning genotypes were similar, with 12CS_028 and 12CS_068 in S15-N15-D15 mega-environment and 12CS_050 in S14, 12CS_120 in D14, 12CS_037 in N14, and 12CS_050 in S14. For Hlm, PC1 and PC2 explained $72.7 \%$ of the total G + GE (Figure $4 \mathrm{~b}$ ). The polygon view showed five genotype sections, with the S15-N15 mega-environment clustered together with the N14 and D15 mega-environments. In this larger group of environments, 12CS_028 and 12CS_031 were the best genotypes. D14 and S14 remained distinct mega-environments, with 12CS_069 and 12CS_037 being the best genotypes in D14 and S14, respectively. Interestingly, 12CS_028, which was the best genotype for pod yield in S15-N15, also showed good haulm yield performance in this mega-environment. In contrast, 12CS_037 was the best genotype for pod yield in the N14 mega-environment, and the best genotype for haulm yield in S14. Finally, for HSW, PC1 and PC2 explained 94.4\% of the total G + GE. In the GGE biplot for HSW, all five mega-environments clustered into one larger mega-environment, with 12CS_069 and 12CS_031 as the best performing genotypes (Figure 4c).

The performance and stability of the genotypes across mega-environments were also analyzed. 12CS_120 was the best genotype for yield stability ( $S C=0.04$ ). The 12CS_028 genotype combined good yield stability $(S C=0.12)$ with haulm yield $(S C=0.35)$, as well as pod and seed length $(S C=0.6$ and 0.002, respectively). 12CS_069 and 12CS_031 combined high HPW, HSW, PWI, and SWI stability, with SCs ranging from 0 to 0.6 . 


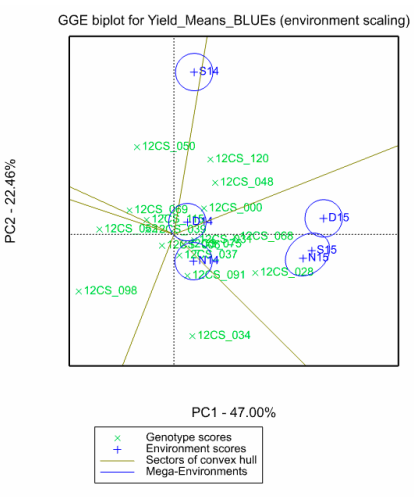

(a)

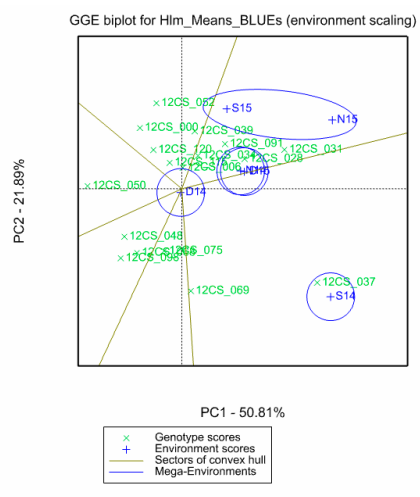

(b)

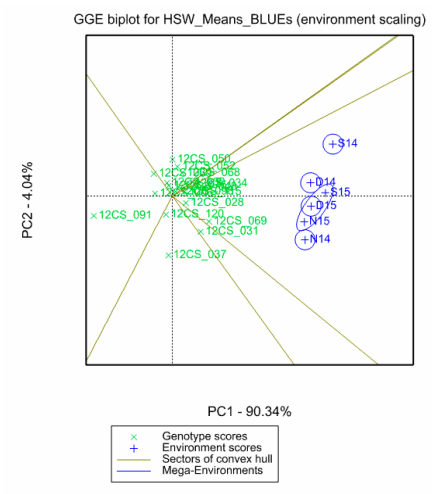

(c)

Figure 4. Genotype $\times$ environment interaction effects (GGE) biplot based on mega-environments. Mega-environments identified in the AMMI analysis are represented in blue, genotypes are in green, and the polygon view is in brown. (a) GGE biplot for pod yield (Yield), (b) GGE biplot for haulm yield (Hlm), and (c) GGE biplot for 100 seed weight (HSW).

\section{Discussion}

\subsection{Wild Alleles Contributed Positive Variation to Yield and Yield Related Traits}

In our study, 16 CSSLs were evaluated for yield and yield-related traits in six environments. We found that wild alleles do not confer significant pod yield disadvantages for most of the lines in most of the environments, except for the 12CS_098 line, which showed a significantly lower yield than Fleur11 in four out of the six environments. Some lines exhibited a higher yield than Fleur11 in at least three environments, even though this increase was not always significant in all environments. This is particularly true for 12CS_028 and 12CS_120, which showed good pod yield performance and stability. Moreover, 12CS_028 combined good pod and haulm yield, making this line an excellent candidate for dual purpose variety in Sahelian zones, where the two traits have similar economical value. Yield increase in crosses involving wild species have been reported in tomatoes, with S. pimpenellifolium or S. hirsutum used as wild donors $[19,56]$; in rice, with O. rufipogon, O. glaberrima and O. nirvara used as donor parents [57-59]; and in many other crop species (for review, see [60]). One interesting results of this study is the behavior of the 12CS_091 line, which has significantly smaller pod and seed size than Fleur11 in all environments, but similar pod yield in five environments. To explain this result, we are hypothesizing that a smaller pod is compensated for by higher pod numbers, leading to a comparable pod yield. This suggests that pod number is much more correlated to yield than pod size is. In soybeans, a higher correlation between pod number and yield than between seed size and yield has been reported [61]. Data on pod numbers have not been collected in our study; thus, further investigations are needed to confirm the compensation effect of pod numbers in the 12CS_091 line. Our study also showed that none of the CSSLs had superior yield in the driest environment (D14). This could be explained by the geographic origins of the wild diploid species used to build the synthetic tetraploid. The A (A. duranensis V14167) and B (A. ipaensis K30076) genome donors of the synthetic tetraploid used in this study were collected in Northern Argentina and Southern Bolivia, respectively [62], in humid regions where annual rainfall ranged between $500 \mathrm{~mm}$ and $1200 \mathrm{~mm}$ [63]. These species are probably less adapted to dry environments $(<450 \mathrm{~mm})$ with very erratic rainfall patterns. However, since the 16 CSSLs that have been evaluated in this study have been selected based on previous QTL results, and represent approximately $23 \%$ of the wild donor genome, one cannot exclude that wild regions conferring yield under drought stress may exist elsewhere in the wild donor genome. A more thorough characterization of the whole CSSL population in dry conditions could potentially allow the identification of positive introgressions for yield under drought stress. 
In this study, we also identified several CSSLs that have larger pods and seeds than the recurrent parent Fleur11. This increase was clearly explained by higher pod and seed length and width, leading to higher 100 seed weight (HSW). One of our most striking results is the high increase in HSW observed for the lines 12CS_069 and 12CS_031 reaching up to 20.6\% (11.05 g). This increase was observed in all environments, reflecting the high stability of the wild allele effects for this trait. Transgressive segregation for seed size trait was also reported in the wild relative crop's crosses [64,65]. In our study, the wild chromosome segment that confers seed size increase in a CSSL line 12CS_069 is about $13 \mathrm{cM}$ in length and is located at the distal end (bottom) of chromosome B06 [47]. Interestingly, the distal end of chromosome 6 has been reported as a location where recombination between A and B homologous chromosomes has occurred, both in cultivated species and in crosses involving a synthetic tetraploid $[62,66,67]$. Many cultivated peanut varieties have been reported to be tetrasomic, with AAAA genome composition at this genomic region $[62,68]$. Assuming that Fleur11 displays the AAAA genome type at this region, the A. ipaensis introgression at the distal end of chromosome B06 could have restored the genome composition to AABB type in the 12CS_069 line. One could hypothesize that this change in genome type from AAAA to AABB is responsible for the increase in seed size observed for this line. The frequency of tetrasomy occurrence in cultivated peanut genomes [68] raises the question of the role of the genome modification in shaping agro-morphological traits in cultivated peanuts, and of the gain or the loss one could produce with the restoration of the genome types using wild species.

\subsection{CSSLs Are Accurate Populations for QTL Validation and New QTL Discovery}

The 16 CSSL lines evaluated in this study were selected based on the genome position of wild introgressed segments (Table 1), offering the opportunity for validating several QTLs detected in a previous AB-QTL study [47]. We succeeded in validating most of the QTLs that were detected in the AB-QTL study. This was particularly the case for QTLs involved in pod and seed size variation in the linkage groups A07 (top), A08, A09, and B06, carried by the 12CS_091, 12CS_039, 12CS_028 and 12CS_031, and 12CS_050 and 12CS_069 lines, respectively. These results were expected given the high broad sense heritability observed for these traits in the two studies (between 0.74 and 0.97). However, we were not able to validate QTLs for pod maturity previously detected on chromosomes B11 and B06 using the CSSLs 12CS_068, 12CS_050, and 12CS_069. Similarly, a QTL for haulm yield was confirmed only in one region (B06 qHW region in line 12CS_069) and one environment (S14), while QTLs were detected in two regions (A02 and A06) in the AB-QTL study. This could be explained by the fact that the variation of these two traits is highly influenced by the environment (environment effects accounted for more than $50 \%$ of the total variation for this traits). The confounding effects of environment on QTL validation was reported in many crop species, including maize [69] and soybeans [70].

In addition to the validated QTLs, we identified several new QTLs for pod and seed size that were not detected in the AB-QTL study. This was the case for HPW QTLs carried by 12CS_031 and 12CS069; HSW QTLs carried by 12CS_031, 12CS_34, 12CS_50, 12CS_069, and 12CS_115; for PL and SL QTLs carried by 12CS_050, 12CS_052, 12CS_068, 12CS_069, and 12CS_120; and SWI QTLs carried by 12CS_028, 12CS_031, 12CS_048, 12CS_052, 12CS_098, and 12CS_115. Except for HSW with 12CS_031 and 12CS_069, the number of environments where these QTLs were detected varied between one and four, attesting to QTL + environmental interactions. These QTLs were not detected in the previous study, probably because of the confounding effects of the environment, the population size and structure (the AB-QTL population was $142 \mathrm{BC}_{3} \mathrm{~F}_{1}$ and $\mathrm{BC}_{2} \mathrm{~F}_{2}$, derived from $44 \mathrm{BC}_{2} \mathrm{~F}_{1}$ ), and the higher percentage of wild species genome in the AB-QTL population leading to a higher frequency of wild alleles with negative effects. One compelling example of this latter point is the QTLs for pod and seed SL increase in 12CS_034 and 12CS_037, whereas they were selected based on wild alleles at QTL regions that reduce seed and pod widths. These two lines both carry a wild chromosome segment located at the distal end (bottom) of chromosome A07 and in the case of 12CS_037, one additional segment at the distal end of chromosome B05 (Figure 1) [51]. Pod length QTLs have not been detected in these regions in the AB-QTL study, probably because of the masking effects of the seed size reduction QTLs 
in linkage disequilibrium on the top of linkage groups A07 and B05 [47]. The successive backcrossing generations for producing the CSSL population have separated the two regions, allowing detection of these new pod length QTLs. The accuracy of the CSSL population for discovering new QTLs has been also reported in $A$. thaliana [71], and in rice [72,73]. Another interesting example of QTL validation concerns the QTLs for pod weight $(q P W)$ per plant and for pod number $(q P N)$ per plant, which were co-localized in a region of approximately $26 \mathrm{~cm}$, located at the proximal end (top) of linkage group A01. This region is covered by the CSSLs 12CS_075, 12CS_115, and 12CS_120 [51]. Among these three lines, one (12CS_120) exhibited higher yields than Fleur11 in three environments. Pod number and weight per plant are key components of pod yield in legume crop species [74-76]; thus, it is likely that $q P W$ and $q P N$ QTLs detected in the AB-QTL correspond to the pod yield QTL that was observed for the 12CS_120 line in our study.

\section{Conclusions}

In this study, we showed that CSSLs are a powerful mapping population for validating QTLs and identifying new ones. We confirmed that segments from the wild species A. duranensis and A. ipaensis could confer significant pod yield advantages in some environments and larger seeds than Fleur11. Our study demonstrates that CSSLs are valuable tools for bringing favorable alleles from wild species that have been left behind during the domestication process back into the cultivated genetic background. Considering the potential of the CSSL population for mendelizing QTLs, one future perspective of this work will consist of pyramiding QTLs to analyze their additive effect, as well as their interaction.

Supplementary Materials: The following are available online at http://www.mdpi.com/2073-4395/10/4/583/s1; Figure S1: Boxplot of hundred pod weights (HPWs), constructed with raw data derived from the evaluation of 16 CSSLs and Fleur11 in six environments; Figure S2: Boxplot of hundred seed weights (HSWs), constructed with raw data derived from the evaluation of 16 CSSLs and Fleur11 in six environments; Figure S3: Boxplot of pod lengths (PLs), constructed with raw data derived from the evaluation of 16 CSSLs and Fleur11 in six environments; Figure S4: Boxplot of seed lengths (SLs), constructed with raw data derived from the evaluation of 16 CSSLs and Fleur11 in six environments; Figure S5: Boxplot of pod widths (PWIs), constructed with raw data derived from the evaluation of 16 CSSLs and Fleur11 in six environments; Figure S6: Boxplot of seed widths (SWIs), constructed with raw data derived from the evaluation of 16 CSSLs and Fleur11 in six environments; Figure S7: Boxplot of pod yields (Yield), constructed with raw data derived from the evaluation of 16 CSSLs and Fleur11 in six environments; Figure S8: Boxplot of haulm yields (Hlm), constructed with raw data derived from the evaluation of 16 CSSLs and Fleur11 in six environments; Figure S9: Boxplot of the percentages of pod maturity (Mat), constructed with raw data derived from the evaluation of 16 CSSLs and Fleur11 in six environments; Table S1: Dunnett multiple comparison test between the CSSLs and Fleur11 for HPW and HSW traits; Table S2: Dunnett multiple comparison test between the CSSLs and Fleur11 for PL and SL traits; Table S3: Dunnett multiple comparison test between the CSSLs and Fleur11 for PWI and SWI traits; Table S4: Dunnett multiple comparison test between the CSSLs and Fleur11 for Hlm, Mat, and Yield traits; Table S5: AMMI analysis of variance across the five mega-environments

Author Contributions: H.-A.T. designed and coordinated the study, was involved in phenotyping data collection and data analysis, and drafted the manuscript; J.R.N. was involved in phenotyping and data collection and with manuscript review; C.D. helped with data analysis and reviewed the manuscript, M.S. was involved in phenotyping and data collection; A.S.; D.S. reviewed the manuscript; J.-F.R. was involved in data analysis and editing of the manuscript.; D.F. designed and coordinated the study, and was involved in the drafting and editing of the manuscript. All authors have read and agree to the published version of the manuscript.

Funding: The Western African Agricultural Productivity Program (WAAPP-Senegal) funded this study.

Conflicts of Interest: The authors declare no conflict of interest.

\section{References}

1. Davis, J.P.; Dean, L.L. Peanut composition, flavor and nutrition. In Peanuts: Genetics, Processing, and Utilization; Stalker, H.T., Wilson Richard, F., Eds.; Academic Press and AOCS Press: Cambridge, MA, USA, 2016; pp. 289-345.

2. FAOSTAT. Food and Agriculture Organization -Statistical Database. Available online: www.fao.org/faostat/ fr/2017 (accessed on 12 December 2019).

3. Husted, L. Cytological Studies an the Peanut, Arachis. Cytologia (Tokyo) 1933, 5, 109-117. [CrossRef]

4. Husted, L. Cytological Studies an the Peanut, Arachis. II. Cytologia (Tokyo) 1936, 7, 396-423. [CrossRef] 
5. Stebbins, G.L. Self Fertilization and Population Variability in the Higher Plants. Am. Nat. 1957, 91, $337-354$. [CrossRef]

6. Seijo, J.G.; Lavia, G.I.; Fernandez, A.; Krapovickas, A.; Ducasse, D.; Moscone, E.A. Physical mapping of the $5 S$ and 18S-25S rRNA genes by FISH as evidence that Arachis duranensis and A. ipaensis are the wild diploid progenitors of A. hypogaea (Leguminosae). Am. J. Bot. 2004, 91, 1294-1303. [CrossRef] [PubMed]

7. Grabiele, M.; Chalup, L.; Robledo, G.; Seijo, G. Genetic and geographic origin of domesticated peanut as evidenced by 5 S rDNA and chloroplast DNA sequences. Plant Syst. Evol. 2012, 298, 1151-1165. [CrossRef]

8. Kochert, G.; Halward, T.; Branch, W.D.; Simpson, C.E. RFLP variability in peanut (Arachis hypogaea L.) cultivars and wild species. TAG Theor. Appl. Genet. Theor. Angew. Genet. 1991, 81, 565-570. [CrossRef]

9. Kochert, G.; Stalker, H.T.; Gimenes, M.; Galgaro, L.; Lopes, C.R.; Moore, K. RFLP and Cytogenetic Evidence on the Origin and Evolution of Allotetraploid Domesticated Peanut, Arachis hypogaea (Leguminosae). Am. J. Bot. 1996, 83, 1282-1291. [CrossRef]

10. Seijo, G.; Lavia, G.I.; Fernández, A.; Krapovickas, A.; Ducasse, D.A.; Bertioli, D.J.; Moscone, E.A. Genomic relationships between the cultivated peanut (Arachis hypogaea, Leguminosae) and its close relatives revealed by double GISH. Am. J. Bot. 2007, 94, 1963-1971. [CrossRef]

11. Halward, T.M.; Stalker, H.T.; Larue, E.A.; Kochert, G. Genetic variation detectable with molecular markers among unadapted germ-plasm resources of cultivated peanut and related wild species. Genome 1991, 34, 1013-1020. [CrossRef]

12. Halward, T.; Stalker, T.; LaRue, E.; Kochert, G. Use of single-primer DNA amplifications in genetic studies of peanut (Arachis hypogaea L.). Plant Mol. Biol. 1992, 18, 315-325. [CrossRef]

13. He, G.; Prakash, C.S. Identification of polymorphic DNA markers in cultivated peanut (Arachis hypogaea L.). Euphytica 1997, 97, 143-149. [CrossRef]

14. Subramanian, V.; Gurtu, S.; Rao, R.N.; Nigam, S.N. Identification of DNA polymorphism in cultivated groundnut using random amplified polymorphic DNA (RAPD) assay. Genome 2000, 43, 656-660. [CrossRef] [PubMed]

15. Raina, S.N.; Rani, V.; Kojima, T.; Ogihara, Y.; Singh, K.P.; Devarumath, R.M. RAPD and ISSR fingerprints as useful genetic markers for analysis of genetic diversity, varietal identification, and phylogenetic relationships in peanut (Arachis hypogaea) cultivars and wild species. Genome 2001, 44, 763-772. [CrossRef] [PubMed]

16. Gimenes, M.A.; Lopes, C.R.; Valls, J.F.M. Genetic relationships among Arachis species based on AFLP. Genet. Mol. Biol. 2002, 25, 349-353. [CrossRef]

17. Milla, S.R.; Isleib, T.G.; Stalker, H.T. Taxonomic relationships among Arachis sect. Arachis species as revealed by AFLP markers. Genome 2005, 48, 1-11. [PubMed]

18. Cuc, L.M.; Mace, E.S.; Crouch, J.H.; Quang, V.D.; Long, T.D.; Varshney, R.K. Isolation and characterization of novel microsatellite markers and their application for diversity assessment in cultivated groundnut (Arachis hypogaea). BMC Plant Biol. 2008, 8, 55. [CrossRef]

19. Tanksley, S.D.; Grandillo, S.; Fulton, T.M.; Zamir, D.; Eshed, Y.; Petiard, V.; Lopez, J.; Beck-Bunn, T. Advanced backcross QTL analysis in a cross between an elite processing line of tomato and its wild relative L. pimpinellifolium. Theor. Appl. Genet. 1996, 92, 213-224. [CrossRef]

20. Fulton, T.M.; Grandillo, S.; Beck-Bunn, T.; Fridman, E.; Frampton, A.; Lopez, J.; Petiard, V.; Uhlig, J.; Zamir, D.; Tanksley, S.D. Advanced backcross QTL analysis of a Lycopersicon esculentum $\times$ Lycopersicon parviflorum cross. Theor. Appl. Genet. 2000, 100, 1025-1042. [CrossRef]

21. Gur, A.; Zamir, D. Unused natural variation can lift yield barriers in plant breeding. PLoS Biol. 2004, 2, e245. [CrossRef]

22. Causse, M.; Duffé, P.; C Gomez, M.; Buret, M.; Damidaux, R.; Zamir, D.; Gur, A.; Chevalier, C.; Lemaire-Chamley, M.; Rothan, C. A Genetic Map of Candidate Genes and QTLs Involved in Tomato Fruit Size and Composition. J. Exp. Bot. 2004, 55, 1671-1685. [CrossRef]

23. Xiao, J.; Li, J.; Grandillo, S.; Ahn, S.N.; Yuan, L.; Tanksley, S.D.; McCouch, S.R. Identification of trait-improving quantitative trait loci alleles from a wild rice relative, Oryza rufipogon. Genetics 1998, 150, 899-909. [PubMed]

24. Moncada, P.; Martínez, C.P.; Borrero, J.; Chatel, M.; Gauch Jr, H.; Guimaraes, E.; Tohme, J.; McCouch, S.R. Quantitative trait loci for yield and yield components in an Oryza sativa×Oryza rufipogon BC2F2 population evaluated in an upland environment. Theor. Appl. Genet. 2001, 102, 41-52. [CrossRef] 
25. Thomson, M.J.; Tai, T.H.; McClung, A.M.; Lai, X.-H.; Hinga, M.E.; Lobos, K.B.; Xu, Y.; Martinez, C.P.; McCouch, S.R. Mapping quantitative trait loci for yield, yield components and morphological traits in an advanced backcross population between Oryza rufipogon and the Oryza sativa cultivar Jefferson. TAG Theor. Appl. Genet. Theor. Angew. Genet. 2003, 107, 479-493. [CrossRef] [PubMed]

26. Septiningsih, E.M.; Prasetiyono, J.; Lubis, E.; Tai, T.H.; Tjubaryat, T.; Moeljopawiro, S.; McCouch, S.R. Identification of quantitative trait loci for yield and yield components in an advanced backcross population derived from the Oryza sativa variety IR64 and the wild relative O. rufipogon. TAG Theor. Appl. Genet. Theor. Angew. Genet. 2003, 107, 1419-1432. [CrossRef] [PubMed]

27. Li, J.; Xiao, J.; Grandillo, S.; Jiang, L.; Wan, Y.; Deng, Q.; Yuan, L.; McCouch, S.R. QTL detection for rice grain quality traits using an interspecific backcross population derived from cultivated Asian $(O$. sativa L.) and African (O. glaberrima S.) rice. Genome 2004, 47, 697-704. [CrossRef]

28. Shah, M.M.; Gill, K.S.; Baenziger, P.S.; Yen, Y.; Kaeppler, S.M.; Ariyarathne, H.M. Molecular Mapping of Loci for Agronomic Traits on Chromosome 3A of Bread Wheat. Crop Sci. 1999, 39, 1728-1732. [CrossRef]

29. Börner, A.; Schumann, E.; Fürste, A.; Cöster, H.; Leithold, B.; Röder, M.; Weber, W. Mapping of quantitative trait loci determining agronomic important characters in hexaploid wheat (Triticum aestivum L.). Theor. Appl. Genet. 2002, 105, 921-936. [CrossRef]

30. Huang, X.Q.; Cöster, H.; Ganal, M.W.; Röder, M.S. Advanced backcross QTL analysis for the identification of quantitative trait loci alleles from wild relatives of wheat (Triticum aestivum L.). Theor. Appl. Genet. 2003, 106, 1379-1389. [CrossRef]

31. Chaim, A.B.; Paran, I.; Grube, R.C.; Jahn, M.; Van Wijk, R.; Peleman, J. QTL mapping of fruit-related traits in pepper (Capsicum annuum). Theor. Appl. Genet. 2001, 102, 1016-1028. [CrossRef]

32. Rao, G.U.; Ben Chaim, A.; Borovsky, Y.; Paran, I. Mapping of yield-related QTLs in pepper in an interspecific cross of Capsicum annuum and C. frutescens. TAG Theor. Appl. Genet. Theor. Angew. Genet. 2003, 106, 1457-1466. [CrossRef]

33. Dwivedi, N.; Kumar, R.; Paliwal, R.; Kumar, U.; Kumar, S.; Singh, M.; Singh, R.K. QTL mapping for important horticultural traits in pepper (Capsicum annuum L.). J. Plant Biochem. Biotechnol. 2015, 24, 154-160. [CrossRef]

34. Stalker, H.T.; Tallury, S.P.; Ozias-Akins, P.; Bertioli, D.; Bertioli, S.L. The value of diploid peanut relatives for breeding and genomics. Peanut Sci. 2013, 40,70-88. [CrossRef]

35. Sharma, S.; Pandey, M.K.; Sudini, H.; Upadhyaya, H.D.; Varshney, R.K. Harnessing Genetic Diversity of Wild Arachis Species for Genetic Enhancement of Cultivated Peanut. Crop Sci. 2017, 57, 1121-1131. [CrossRef]

36. Fávero, A.P.; Simpson, C.E.; Valls, J.F.M.; Vello, N.A. Study of the Evolution of Cultivated Peanut through Crossability Studies among Arachis ipaënsis, A. duranensis, and A. hypogaea. Crop Sci. 2006, 46, 1546-1552. [CrossRef]

37. Mallikarjuna, N. Production of hybrids between Arachis hypogaea and A. chiquitana (section Procumbentes). Peanut Sci. 2005, 32, 148-152. [CrossRef]

38. Mallikarjuna, N.; Hoisington, D. Peanut improvement: Production of fertile hybrids and backcross progeny between Arachis hypogaea and A. kretschmeri. Food Secur. 2009, 1, 457-462. [CrossRef]

39. Mallikarjuna, N.; Senthilvel, S.; Hoisington, D. Development of new sources of tetraploid Arachis to broaden the genetic base of cultivated groundnut (Arachis hypogaea L.). Genet. Resour. Crop Evol. 2011, 58, 889-907. [CrossRef]

40. Rami, J.-F.; Leal-Bertioli, S.C.M.; Foncéka, D.; Moretzsohn, M.C.; Bertioli, D.J. Groundnut. In Alien Gene Transfer in Crop Plants; Pratap, A., Kumar, J., Eds.; Springer: New York, NY, USA, 2014; Volume 2, pp. 253-279, ISBN 978-1-4614-9571-0.

41. Stalker, H.T. Utilizing wild species for peanut improvement. Crop Sci. 2017, 57, 1102-1120. [CrossRef]

42. Nagy, E.D.; Chu, Y.; Guo, Y.; Khanal, S.; Tang, S.; Li, Y.; Dong, W.B.; Timper, P.; Taylor, C.; Ozias-Akins, P.; et al. Recombination is suppressed in an alien introgression in peanut harboring Rma, a dominant root-knot nematode resistance gene. Mol. Breed. 2010, 26, 357-370. [CrossRef]

43. Leal-Bertioli, S.C.M.; Cavalcante, U.; Gouvea, E.G.; Ballén-Taborda, C.; Shirasawa, K.; Guimarães, P.M.; Jackson, S.A.; Bertioli, D.J.; Moretzsohn, M.C. Identification of QTLs for Rust Resistance in the Peanut Wild Species Arachis magna and the Development of KASP Markers for Marker-Assisted Selection. G3 Genes Genomes Genet. 2015, 5, 1403-1413. 
44. Leal-Bertioli, S.C.M.; Moretzsohn, M.C.; Roberts, P.A.; Ballén-Taborda, C.; Borba, T.C.O.; Valdisser, P.A.; Vianello, R.P.; Araújo, A.C.G.; Guimarães, P.M.; Bertioli, D.J. Genetic Mapping of Resistance to Meloidogyne arenaria in Arachis stenosperma: A New Source of Nematode Resistance for Peanut. G3 Genes Genomes Genet. 2016, 6, 377-390. [CrossRef] [PubMed]

45. Rick, C.M.; Chetelat, R.T. Utilization of related wild species for tomato improvement. Acta Hortic. 1995, 21-38. [CrossRef]

46. Jordan, D.; Butler, D.; Henzell, B.; Drenth, J.; McIntyre, L. Diversification of Australian sorghum using wild relatives, New Directions for a Diverse Planet. In Proceedings of the 4th International Crop Science Congress, Brisbane, Australia, 26 September-1 October 2004.

47. Fonceka, D.; Tossim, H.-A.; Rivallan, R.; Vignes, H.; Faye, I.; Ndoye, O.; Moretzsohn, M.C.; Bertioli, D.J.; Glaszmann, J.-C.; Courtois, B.; et al. Fostered and left behind alleles in peanut: Interspecific QTL mapping reveals footprints of domestication and useful natural variation for breeding. BMC Plant Biol. 2012, 12, 26. [CrossRef] [PubMed]

48. Tanksley, S.D. Seed Banks and Molecular Maps: Unlocking Genetic Potential from the Wild. Science 1997, 277, 1063-1066. [CrossRef]

49. Zamir, D. Improving plant breeding with exotic genetic libraries. Nat. Rev. Genet. 2001, 2, 983-989. [CrossRef]

50. Foncéka, D. Elargissement de la base génétique de l'arachide cultivée (\# Arachis hypogaea\#): Applications pour la construction de populations, l'identification de QTL et l'amélioration de l'espèce cultivée; Montpellier SupAgro: Montpellier, France, 2010; Available online: https://www.theses.fr/2010NSAM0023 (accessed on 12 December 2019).

51. Fonceka, D.; Tossim, H.-A.; Rivallan, R.; Vignes, H.; Lacut, E.; de Bellis, F.; Faye, I.; Ndoye, O.; Leal-Bertioli, S.C.M.; Valls, J.F.M.; et al. Construction of Chromosome Segment Substitution Lines in Peanut (Arachis hypogaea L.) Using a Wild Synthetic and QTL Mapping for Plant Morphology. PLoS ONE 2012, 7, e48642. [CrossRef]

52. Van Rossum, B.-J.; van Eeuwijk, F.; Boer, M.; Malosetti, M.; Bustos-Korts, D.; Millet, E.; Paulo, J.; Verouden, M.; Kruijer, W.; Wehrens, R.; et al. statgenSTA: Single Trial Analysis (STA) of Field Trials. R Package version 1.0.4. 2020. Available online: https://rdrr.io/cran/statgenSTA/ (accessed on 12 December 2019).

53. Hothorn, T.; Bretz, F.; Westfall, P. Simultaneous Inference in General Parametric Models. Biom. J. 2008, 50, 346-363. [CrossRef]

54. Yan, W.; Kang, M.S. GGE Biplot Analysis: A Graphical Tool for Breeders, Geneticists, and Agronomists; CRC Press: Boca Raton, FL, USA, 2003; ISBN 978-0-429-12272-9.

55. Breeding Management System | Integrated Breeding Platform | Plant Breeding Software. Available online: https://bmspro.io/1824/breeding-management-system/tutorials/maize-multi-site-gxe-analysis (accessed on 7 April 2020).

56. Eshed, Y.; Zamir, D. Introgressions fromLycopersicon pennellii can improve the soluble-solids yield of tomato hybrids. Theor. Appl. Genet. 1994, 88, 891-897. [CrossRef]

57. McCouch, S. Diversifying selection in plant breeding. PLoS Biol. 2004, 2, e347. [CrossRef]

58. Gutiérrez, A.G.; Carabalí, S.J.; Giraldo, O.X.; Martínez, C.P.; Correa, F.; Prado, G.; Tohme, J.; Lorieux, M. Identification of a Rice stripe necrosis virus resistance locus and yield component QTLs using Oryza sativa $\times$ O. glaberrima introgression lines. BMC Plant Biol. 2010, 10, 6. [CrossRef] [PubMed]

59. Ma, X.; Fu, Y.; Zhao, X.; Jiang, L.; Zhu, Z.; Gu, P.; Xu, W.; Su, Z.; Sun, C.; Tan, L. Genomic structure analysis of a set of Oryza nivara introgression lines and identification of yield-associated QTLs using whole-genome resequencing. Sci. Rep. 2016, 6, 27425. [CrossRef] [PubMed]

60. Swamy, B.P.M.; Sarla, N. Yield-enhancing quantitative trait loci (QTLs) from wild species. Biotechnol. Adv. 2008, 26, 106-120. [CrossRef] [PubMed]

61. Board, J.E.; Kang, M.S.; Harville, B.G. Path Analyses Identify Indirect Selection Criteria for Yield of Late-Planted Soybean. Crop Sci. 1997, 37. [CrossRef]

62. Bertioli, D.J.; Cannon, S.B.; Froenicke, L.; Huang, G.; Farmer, A.D.; Cannon, E.K.S.; Liu, X.; Gao, D.; Clevenger, J.; Dash, S.; et al. The genome sequences of Arachis duranensis and Arachis ipaensis, the diploid ancestors of cultivated peanut. Nat. Genet. 2016, 48, 438-446. [CrossRef]

63. Ferguson, M.E.; Bramel, P.J.; Chandra, S. Gene diversity among botanical varieties in peanut (Arachis hypogaea L.). Crop Sci. 2004, 44, 1847-1854. [CrossRef] 
64. Rieseberg, L.H.; Archer, M.A.; Wayne, R.K. Transgressive segregation, adaptation and speciation. Heredity 1999, 83, 363-372. [CrossRef]

65. Vega, U.; Frey, K.J. Transgressive segregation in inter and intraspecific crosses of barley. Euphytica 1980, 29, 585-594. [CrossRef]

66. Nguepjop, J.R.; Tossim, H.-A.; Bell, J.M.; Rami, J.-F.; Sharma, S.; Courtois, B.; Mallikarjuna, N.; Sane, D.; Fonceka, D. Evidence of Genomic Exchanges between Homeologous Chromosomes in a Cross of Peanut with Newly Synthetized Allotetraploid Hybrids. Front. Plant Sci. 2016, 7, 1635. [CrossRef]

67. Leal-Bertioli, S.; Shirasawa, K.; Abernathy, B.; Moretzsohn, M.; Chavarro, C.; Clevenger, J.; Ozias-Akins, P.; Jackson, S.; Bertioli, D. Tetrasomic Recombination Is Surprisingly Frequent in Allotetraploid Arachis. Genetics 2015, 199, 1093-1105. [CrossRef]

68. Clevenger, J.; Chu, Y.; Chavarro, C.; Agarwal, G.; Bertioli, D.J.; Leal-Bertioli, S.C.M.; Pandey, M.K.; Vaughn, J.; Abernathy, B.; Barkley, N.A.; et al. Genome-wide SNP Genotyping Resolves Signatures of Selection and Tetrasomic Recombination in Peanut. Mol. Plant 2017, 10, 309-322. [CrossRef] [PubMed]

69. Beavis, W.D.; Beavis, W.D.; Beavis, W.D.; Beavis, W.D. The Power and Deceit of QTL Experiments: Lessons from Comparative QTL Studies; ScienceOpen: Berlin, Germany, 1994.

70. Fasoula, V.A.; Harris, D.K.; Boerma, H.R. Validation and Designation of Quantitative Trait Loci for Seed Protein, Seed Oil, and Seed Weight from Two Soybean Populations. Crop Sci. 2004, 44, 1218-1225. [CrossRef]

71. Keurentjes, J.J.B.; Bentsink, L.; Alonso-Blanco, C.; Hanhart, C.J.; Blankestijn-De Vries, H.; Effgen, S.; Vreugdenhil, D.; Koornneef, M. Development of a Near-Isogenic Line Population of Arabidopsis thaliana and Comparison of Mapping Power With a Recombinant Inbred Line Population. Genetics 2007, 175, 891-905. [CrossRef] [PubMed]

72. Wan, J.L.; Zhai, H.Q.; Wan, J.M.; Yasui, H.; Yoshimura, A. Mapping QTL for traits associated with resistance to ferrous iron toxicity in rice (Oryza sativa L.), using japonica chromosome segment substitution lines. Yi Chuan Xue Bao 2003, 30, 893-898. [PubMed]

73. Sun, D.; Jiang, L.; Zhang, Y.; Cheng, X.; Zhai, H.; Wan, J. Detection of QTL associated with rice stripe resistance in cultivar IR24. Acta Agron Sin. 2007, 33, 25-30.

74. Irzykowska, L.; Wolko, B. Interval mapping of QTLs controlling yield-related traits and seed protein content in Pisum sativum. J. Appl. Genet. 2004, 45, 297-306. [PubMed]

75. Timmerman-Vaughan, G.M.; Mills, A.; Whitfield, C.; Frew, T.; Butler, R.; Murray, S.; Lakeman, M.; McCallum, J.; Russell, A.; Wilson, D. Linkage Mapping of QTL for Seed Yield, Yield Components, and Developmental Traits in Pea. Crop Sci. 2005, 45, 1336-1344. [CrossRef]

76. Ayaz, S.; McKENZIE, B.A.; Hill, G.D.; McNEIL, D.L. Variability in yield of four grain legume species in a subhumid temperate environment. II. Yield components. J. Agric. Sci. 2004, 142, 21-28. [CrossRef] 